Original Research Paper

\title{
Metabolite profiling in Mango (Mangifera indica L.) pollen grains in relation to viability
}

\author{
*K.S. Shivashankara, G.A. Geetha and T.K. Roy \\ Division of Plant Physiology and Biochemistry, \\ ICAR-Indian Institute of Horticultural Research, \\ Hessaraghatta Lake Post, Bengaluru - 560 089, Karnataka, India \\ *Email : shivaiihr@yahoo.com
}

\begin{abstract}
Mango productivity is affected mainly by irregular flowering, proportion of bisexual flowers, poor pollination and fertilization and fruit drop. Poor fruit set in some of the varieties may be associated with the lower pollen viability. The present experiment was initiated to assess the viability of pollen grains and their metabolites in three mango cultivars Amrapali, Alphonso and Totapuri which are differing in their fruit set intensity. The profiling of sugars, amino acids and some of the phytohormones were analysed using Liquid Chromatography-Mass Spectrometry (LC-MS/MS). Assessment of pollen grains in three mango cultivars indicated that free sugars such as fructose and glucose, and available amino acids including serine, proline, lysine, phenylalanine, alanine and glutamic acid were predominantly higher in all the cultivars. Phytohormones like IAA, IBA, ABA, GA, zeatin, jasmonic acid and salicylic acid were significantly different in low fruit setting cultivars Alphonso and Totapuri compared to high fruit setting cultivar Amrapali. In cv. Alphonso all the metabolites were higher at anthesis but later decreased drastically compared to cvs. Totapuri and Amrapali. Pollen viability percentage was significantly higher in cv. Amrapali than in cvs. Totapuri, Alphonso. Among all the cultivars, Amrapali maintained better chemical composition at anthesis and also at two hours after anthesis compared to cvs. Totapuri and Alphonso.
\end{abstract}

Key words: Pollen, viability, LC-MS, amino acids, sugars, mango, hormones

\section{INTRODUCTION}

Mango productivity is adversely affected by irregular/ alternate flowering, reduced fruit set, high fruit drop and poor pollen viability. Greater understanding towards flowering physiology and reproductive physiology of mango (Mangifera indica L.) is crucial to overcome these yield complications. Mango floral biology has been studied by many workers (Pimentel et al., 1984; Spencer and Kennard, 1955; Young, 1955; Tsang and Chang, 1983). Mango pollens are characterized by very short viability as well as high sensitivity towards desiccation (Issarakraisila and Considine, 1994). Pollen viability and its germination are also cultivar dependent characters in mango crop (Abourayya et al., 2011; Singh, 1954; Dahshan, 1971; El-Kady, 1973; Desai et al., 1986; El-Masry, 2001 and Abd El-Hadi, 2006). However, reasons for poor pollen viability and its biochemical basis are not yet understood. For effective fertilization, the pollen grains are to be transported to the stigma of the flower at a precise period of time where stigma is highly receptive. In a few cases, where pollen grains are placed before the maximum receptivity period of stigma, they must continue to be viable for a long period to germinate which leads to effective fertilization (Stosser et al., 1996). Pollination outside the window of stigma receptivity period resulted in reduced fruit set or most of the time no fruit set at all in many crops including mango (Herrero, 2003). Therefore, it is essential to understand the metabolite basis of pollen viability and its relationship with fruit set and production.

Mango pollens are 20-45 $\mu \mathrm{m}$ long and possess three symmetrical, narrowing channels along the 
longitudinal margins when it is dehydrated and more spherical or triangular shape when hydrated (Randhawa and Damodaran, 1961; Singh and Singh, 1961). There are many reports suggesting that mango pollen grains are more viable shortly after anther dehiscence and rapidly reduces with time (Mallik, 1957; Singh, 1963; Spencer and Kennard, 1955). It is reported that in warm weather the pollen viability is normally $>90 \%$ in the initial flowering (Mukherjee, 1949; Singh, 1954; Singh and Singh, 1961) however, during cool climate, initial flowering resulted in irregular and non-viable pollen grains (Issarakraisila et al., 1992). Davenport (2009) revealed that mango pollen grains are viable throughout warm temperatures, whereas cool climate can adversely influence pollen grain growth and pollen tube development to the ovule.

Pollen grain samples showed presence of various essential and non-essential amino acids (Basuny et $a l ., 2013)$. It is reported that palm pollen grains contain major essential amino acids constituents like, leucine and lysine (Hassan, 2011). Among available amino acids, proline found to be the maximum and account for $1-2 \%$ of the whole weight of pollen grains (Stanley and Linskens, 1974). Kedzia and HoldernaKedzia (2012) revealed that pollen comprises $10.4 \%$ of essential amino acids such as methionine, lysine, threonine, histidine, leucine, isoleucine, valine, phenylalanine and tryptophan. The stingless bees collected pollen grains from Jandaira area consisted of 17 amino acids, among which, proline was found at the highest concentration. Proline and serine reported to be major amino acids, establishing around $56 \%$ of total free amino acids (da Silva et al., 2014). Digestible carbohydrates have been reported in pollen grains to an extent of $30.8 \%$ and among reducing sugars, mainly fructose and glucose account for $25.7 \%$ (Roulston and Cane, 2000). It is also reported that the sugars such as fructose, glucose and sucrose consists of around ninety percent of all low molecular weight sugars. Such information on the biochemical composition of pollens is lacking in mango.

There is a need for understanding the varietal variation in biochemical composition of pollens in mango which show diversity in pollen viability and fruit set (Abourayya et al., 2011; Abd El-Hadi, 2006). Therefore, the present study was initiated in three commercially valued mango cultivars viz. Alphonso,
Totapuri and Amrapali which differ in fruit set and pollen viability characteristics.

\section{MATERIAL AND METHODS}

The experiment was conducted in ICAR-Indian Institute of Horticultural Research (IIHR), Bengaluru, which is located at $13^{\circ} 58 \mathrm{~N}$ latitude, $78^{\circ} \mathrm{E}$ longitude and $890 \mathrm{~m}$ above mean sea level. Uniformly and healthy grown five trees from each variety were selected for sample collection. The samples were collected at two time intervals after anthesis i.e., 9:00 $\mathrm{AM}$ and 11:00 AM in the morning. The flower samples were brought to lab using petri plates covered with moisture filter papers and immediately processed for biochemical estimation using relevant solvents.

\section{Pollen viability}

Viability of mango pollen grains was assessed using inorganic acid test as explained by Koul and Paliwal's (1961). Adding 4\% sulphuric acid to the freshly collected pollen grains resulted in immediate formation of short pollen tubes which is known as instant pollen tubes. Pollen viability was assessed at anthesis and 2 hours after anthesis.

\section{Biochemical composition of pollen grains}

\section{Assessment of free amino acids}

The free amino acids were extracted and analysed using the methanol: formic acid method (Geetha et $a l ., ., 2016)$. In brief, the free amino acids were extracted using $0.1 \%(\mathrm{v} / \mathrm{v})$ formic acid in $20 \%$ methanol and the mixture was sonicated for about 15 min and centrifuged at $4^{\circ} \mathrm{C}$ in $10,000 \mathrm{rpm}$ for about 20 mins. The extract was filtered using $0.2 \mu \mathrm{m}$ nylon membrane filter and $5 \mu \mathrm{L}$ of sample injected to LCMS/MS column for the amino acid analysis.

\section{LC and MS-MS conditions}

The mobile phase for running the LC program was an aqueous phase of $0.1 \%$ formic acid in water (A) and organic phase of methanol: water (1:1) with $0.1 \%$ formic acid (B). The gradient program starting with $95 \%$ of solvent A to $60 \%$ at 15 mins and back to the initial conditions at 19 mins. The flow rate was 0.1 $\mathrm{mL} / \mathrm{min}$. The analytical column was $2.1 \times 50 \mathrm{~mm}$ UPLC BEH- C18 reverse phase column with $1.7 \mu \mathrm{m}$ particle size, protected by a vanguard BEH C18 with $1.7 \mu \mathrm{m}$ guard column. The elution was supervised by means of a PDA detector and the UPLC column discharge driven directly without any splitting into the TQD-MS/MS (Waters, USA), for amino acid analysis. 


\section{Estimation of hormones}

Phytohormones were analysed by using LC-MS/ MS as described by Geetha et al (2016). The samples were homogenised in 1-propanol: water $(2: 1 ; \mathrm{v} / \mathrm{v})$ with $0.07 \% \mathrm{HCl}$ for different phytohormonal extraction. The supernatant was vaporized to complete dryness and taken into mobile phase, filtered using $0.2 \mu \mathrm{m}$ nylon filter paper and $5 \mu \mathrm{L}$ was injected to LC-MS/MS.

\section{LC and MS-MS conditions}

The mobile phase was composed of solvent (A) water/acetonitrile/acetic acid (95/5/0.05, v/v/v) and solvent (B) acetonitrile/water/acetic acid (95/5/ $0.05, \mathrm{v} / \mathrm{v} / \mathrm{v})$. The gradient program initiated with $85 \%$ solvent A changed to $15 \%$ at 12 mins and from 13 mins the gradient was returned to the initial conditions of $85 \% \mathrm{~A}$ at $15 \mathrm{~min}$. The flow rate was $0.2 \mathrm{~mL} / \mathrm{min}$ and the LC column details are same as mentioned for the amino acid analysis.

\section{Estimation of sugars}

Extraction of different sugars from mango pollen grains was performed as described by Geetha et al (2008). A known quantity of the sample was extracted with $5 \mathrm{~mL}$ of $80 \%$ ethanol. The extract was evaporated to remove traces of alcohol and re-dissolved in mobile phase comprising solvent A and solvent $\mathrm{B}$ in 1:1 ratio, filtered through nylon filter paper and injected to LC-MS/MS (Waters UPLC $\mathrm{H}$ class system fitted with TQD MS/MS system) for analysis.

\section{LC and MS-MS conditions}

The mobile phase comprised of Solvent (A) 80:20Acetonitrile: water and Solvent (B) 30:70Acetonitrile: water with $0.1 \%$ Ammonium hydroxide. The gradient program was used for running LC, initially with $100 \%$ of solvent A to $98 \%$ at end of $15 \mathrm{mins}$ and returned to $100 \%$ solvent $\mathrm{A}$ at 19 mins. The flow rate was $0.1 \mathrm{~mL} /$ min and the analytical column was the same as mentioned for amino acid analysis.

\section{Statistical analysis}

The current work is conducted entirely using CRD with three replicates. Significance differences among the means were analysed using analysis of variance (ANOVA) at $P \leqq 0.05$.

\section{RESULTS AND DISCUSSION}

In the current study the biochemical changes in pollen grains at anthesis and 2 hours after anthesis was analysed in three commercially important mango cultivars Alphonso, Totapuri and Amrapali which are differing in fruit set intensity.

\section{Pollen viability}

Our study on pollen viability by inorganic acid test revealed that the pollen grains of cv. Amrapali had significantly higher viability compared to cvs. Totapuri and Alphonso (Fig. 1). Pollen viability was found to

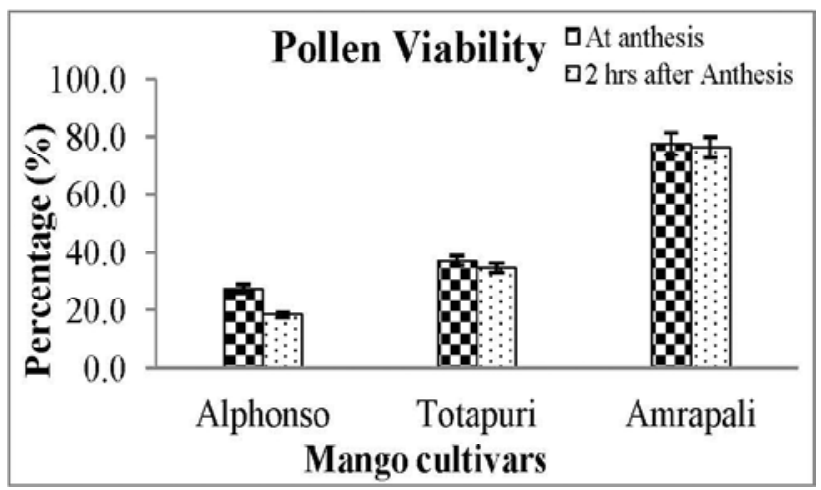

Fig 1. Pollen viability (\% viable pollens) in

cvs. Alphonso, Totapuri and Amrapali at anthesis and 2 hrs after anthesis

decrease $2 \mathrm{hrs}$ after anthesis in cvs. Alphonso and Totapuri, however it remained constant in cv. Amrapali. Earlier literature on mango pollen grains revealed that they are most viable soon after anther dehiscence and viability decreases rapidly afterwards (Sen et al., 1946; Spencer and Kennard, 1955; Mallik, 1957; Singh, 1963). Although the initial percentage of viable pollen grains are reported to be generally $>90 \%$ during warm weather, during cool climate initial flowering resulted in irregular, non-viable pollens (Issarakraisila et al., 1992). It is reported that reduced pollen viability might be due to abnormal development of anthers at low temperatures (Issarakraisila and Considine, 1994). The variations in the pollen viability of different mango cultivars are due to genetic makeup (Abourayya et al., 2011; El-Masry, 2001 and Abd El-Hadi, 2006). Therefore, it is essential to understand whether these variations of pollen viability are due to differences in biochemical composition of pollen grains in the above three cultivars.

\section{Amino acids in pollen grains}

Results revealed that proline was found to be the leading amino acid in pollen grains of all the three 
cultivars. Total free amino acids were higher in Alphonso cultivar compared to the other two cultivars Totapuri and Amrapali. However, most of the amino acids were decreasing with time in cultivar Alphonso on the other hand it remained constant in other two cultivars Totapuri and Amrapali (Table 1). Proline, serine, lysine and phenylalanine are the major amino acids in all the cultivars. These amino acids are higher in Alphonso at anthesis but later i.e., two hours after anthesis decreased to half of its concentration. In other two cultivars Totapuri and Amrapali the amino acid concentration remained constant at anthesis and also at 2 hours after anthesis. Proline was reported to be present in highest percentage in pollens of higher plants and is up to $1-2 \%$ of the whole weight of pollen grains (Stanley and Linskens, 1974). However, in palm trees pollen grains contain leucine and lysine as the major amino acids (Hassan, 2011). In general, pollen grains contain $10.4 \%$ of important amino acids such as methionine, lysine, threonine, histidine, leucine, isoleucine, valine, phenylalanine and tryptophan (Kedzia and Holderna-Kedzia, 2012). Proline was reported to be highest in the Jandaira stingless bees collected pollen grains. They identified 17 amino acids in the bees collected pollen grains and found proline and serine were at higher concentration, comprising around $56 \%$ of overall free amino acids (da Silva et al., 2014). It is reported by earlier workers that the serine is considered to be second highest amino acid present in many pollen grains whereas bee-collected pollen grains from Poland, South Korea and China reported glutamic acid, proline, aspartic acid, leucine and lysine are high concentration (Szczesna, 2006). In our study also serine was found second highest free amino acid recorded in all the three cultivars (Table 1). Mutters et al., (1989) revealed that the proline content was maximum in the male reproductive parts of cowpea plants, whereas proline deficient mutant Arabidopsis plants showed reduced pollen viability signifies the role of proline in pollen grain growth and development. The proline mutated plants are moderately supplemented by spraying proline on inflorescences which resulted in the enhancement of pollen germination in Arabidopsis plants (Mattioli et al., 2012).

Phytohormones play very important role in growth and development of plants especially during reproduction. This study indicated that the IAA content was more at anthesis and later decreased in cultivars Alphonso and Totapuri but increased after anthesis in cv. Amrapali (Table 2). Higher IAA content in pollens of Amrapali may be contributing for the better quality pollens in this cultivar compared to Alphonso and Totapuri. It is reported that Indole-3-acetic acid (IAA) is involved in controlling the development of floral parts such as stamens, gynoecia and ovary, which indirectly supporting the development of ovule and also encouraging axial polarity and polar growth of embryo (Mol et al., 2004; Aloni et al., 2006). Increase in content of IAA in pistil post-pollination processes was also observed indicating the involvement of IAA probably in promoting the pollen tube growth in the pistils (Aloni et al., 2006; Wu et al., 2008). However, only a few reports are available on the role of auxins in pollen development and viability. Auxin is required for floral organ development and pollen production (Cheng et al., 2006) as well as for pollen maturation and anther dehiscence in Arabidopsis (Cecchetti et al., 2013). Pollen germination in stigma was complemented by the increase of ethylene, ABA, IAA and cytokinins (Kovaleva and Zakharova, 2003; 2004). There are earlier reports suggested that ethylene or ethylenereleasing agents produce an increased number of female and bisexual flowers, respectively (Owens et al., 1980). Ethylene content was observed more in cv. Amrapali which is high fruit setting variety and the content was increased to twice after $2 \mathrm{hrs}$ of anthesis and this variety is also known to have higher number of bisexual flowers (Geetha et al., 2016).

Plant growth regulator salicylic acid was high in the pollens of cv. Amrapali compared to other two cultivars and the content of SA increased after anthesis in all the cultivars (Table 2). Among the gibberellins estimated, $\mathrm{GA}_{4}$ was significantly higher in cv. Amrapali and lowest in cv. Alphonso whereas $\mathrm{GA}_{3}$ and $\mathrm{GA}_{7}$ content were similar among the cultivars. $\mathrm{ABA}$ and jasmonates were also significantly higher in cv. Amrapali compared to other two cultivars (Table 2). ABA was increasing with time after anthesis in all the cultivars. Methyl jasmonate was found to increase after anthesis only in cultivar Amrapali. Parish et al., (2013) revealed gibberellins and ABA role in the growth of Tapetum is crucial for the circulation of metabolites to the pollen grains. It is also reported that in Arabidopsis gibberellins are essential for stamen elongation and pollen maturation (Goto and Pharis, 1999) whereas in rice, gibberellins 


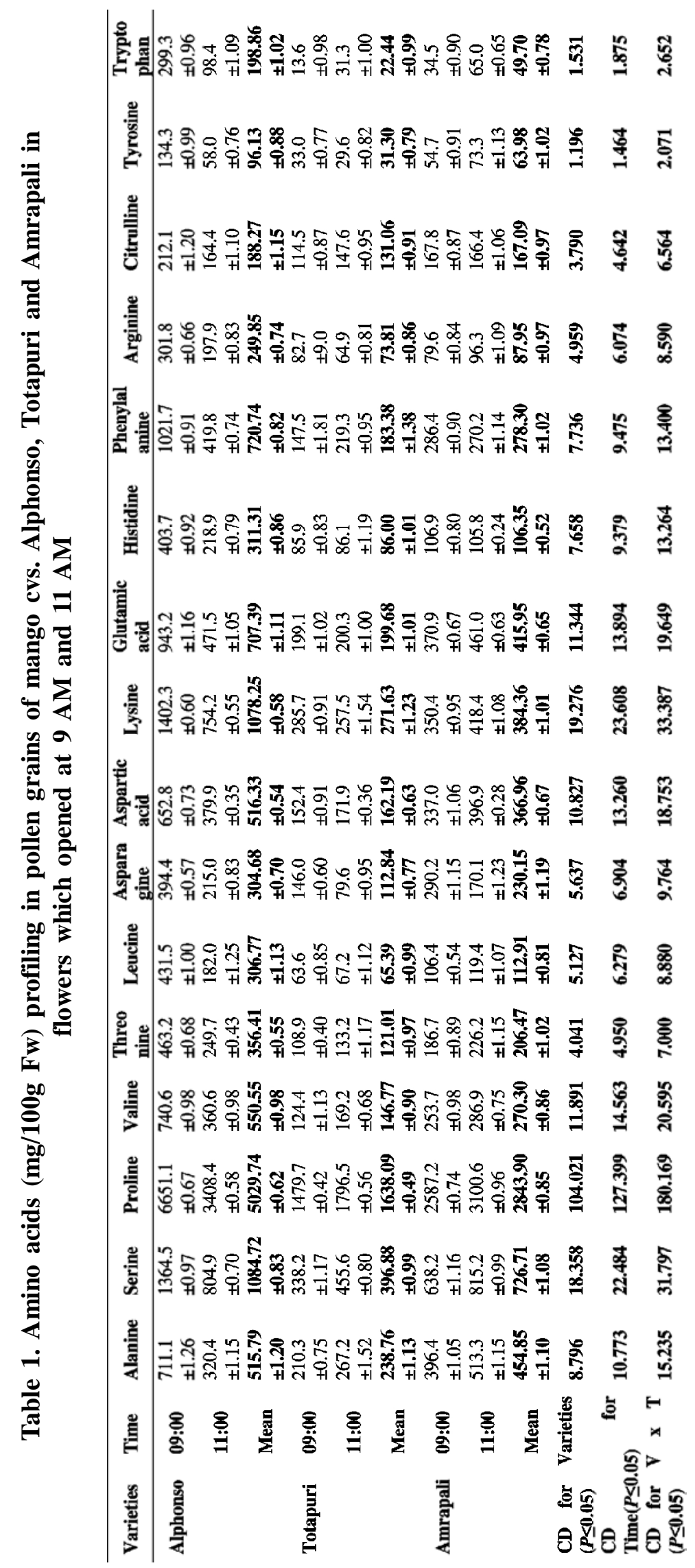




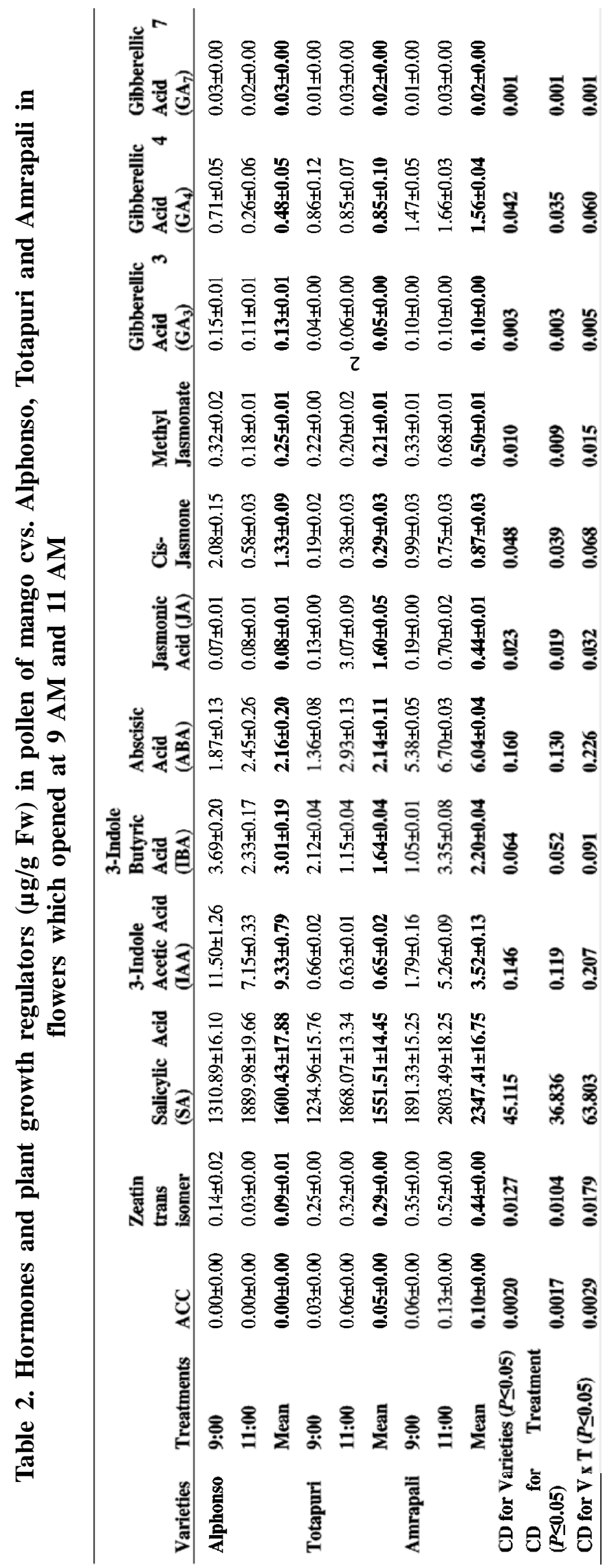


are essential for pollen growth, stamen elongation and pollen development (Chhun et al., 2007).

The sugar accumulation in pollen grains of all the three cultivars also followed similar trend as that of amino acids. Alphonso cultivar recorded higher fructose and glucose contents when compared to the other two cultivars, but the content decreased to half of its concentration with time in Alphonso cultivar however, in the other two cultivars Totapuri and Amrapali sugars remained constant (Table 3). It is reported that pollens collect sucrose throughout their development (Aloni et al., 2001), and subsequent hydrolysis by invertase, the glucose and fructose are generated due to rapid metabolization at the onset of germination (Karni and Aloni, 2002). This is the main reason that in our studies also fructose and glucose concentration was observed in high concentration compared to other sugars in all three mango cultivars. Digestible carbohydrates occur in the pollen grains in the amount of $30.8 \%$ on an average. Reducing sugars, mainly fructose and glucose, are present in about $25.7 \%$ in pollen grains (Roulston and Cane, 2000). Increased content of non-reducing sugars, starch and decreased inorganic phosphates and acid phosphatase activities are reported to be some of the reasons for lower viability (Nishiyama, 1984).

Relationship between the sugar and amino acids with pollen viability and germination is yet to be understood. Lower pollen viability is observed in cv. Alphonso but the pollens had higher amino acids and sugars at anthesis later on decreased. This indicates that these pollen grains may be lacking the enzymes which are useful for the utilisation of sugars and amino acids for germination. The pollen grains of Alphonso cultivar is degraded rapidly compared to cultivars Totapuri and Amrapali which is one of the main constraints for pollen germination and fruit set. Greater fruit set in cv. Amrapali is primarily because of improved pollen viability and enhanced metabolites in pollens compared to cv. Alphonso. Higher content of proline, serine, salicylic acid, glucose and fructose were observed in pollens of cv. Alphonso at anthesis when compared to other cultivars even though Alphonso is low in fruit set.

\section{CONCLUSION}

In the present study, it is observed that pollen viability and metabolites vary significantly between the cultivars. In addition to that higher viability pollens of cv. Amrapali (high fruit set) also recorded lower sugars and amino acids, higher $\mathrm{ABA}, \mathrm{GA}_{4}$, zeatin and salicylic acid when compared to the pollens of Alphonso (low fruit set) indicating that the higher viability may be due to better utilisation of sugars and amino acids and due to higher growth regulators. Further it was

Table 3. Sugar (g/100g Fw) profiling in pollen of mango cvs. Alphonso, Totapuri and Amrapali in flowers which opened at 9 AM and 11 AM

\begin{tabular}{llllll}
\hline Varieties & Time & Fructose & Glucose & Ribose & Sucrose \\
\hline Alphonso & $\mathbf{0 9 : 0 0}$ & $5.63 \pm 0.21$ & $3.34 \pm 0.14$ & $0.13 \pm 0.02$ & $0.28 \pm 0.03$ \\
& $\mathbf{1 1 : 0 0}$ & $2.49 \pm 0.14$ & $1.40 \pm 0.12$ & $0.03 \pm 0.01$ & $0.36 \pm 0.02$ \\
Mean & $\mathbf{4 . 0 6} \pm \mathbf{0 . 1 7}$ & $\mathbf{2 . 3 7} \pm \mathbf{0 . 1 3}$ & $\mathbf{0 . 0 8} \pm \mathbf{0 . 0 2}$ & $\mathbf{0 . 3 2} \pm \mathbf{0 . 0 2}$ \\
Totapuri & $\mathbf{0 9 : 0 0}$ & $1.67 \pm 0.25$ & $1.17 \pm 0.13$ & $0.04 \pm 0.01$ & $0.24 \pm 0.02$ \\
& $\mathbf{1 1 : 0 0}$ & $2.29 \pm 0.09$ & $1.13 \pm 0.07$ & $0.02 \pm 0.00$ & $0.21 \pm 0.02$ \\
& Mean & $\mathbf{1 . 9 8} \pm \mathbf{0 . 1 7}$ & $\mathbf{1 . 1 5} \pm \mathbf{0 . 1 0}$ & $\mathbf{0 . 0 3} \pm \mathbf{0 . 0 1}$ & $\mathbf{0 . 2 2 5} \pm \mathbf{0 . 0 2}$ \\
Amrapali & $\mathbf{0 9 : 0 0}$ & $2.98 \pm 0.11$ & $1.56 \pm 0.20$ & $0.02 \pm 0.01$ & $0.01 \pm 0.01$ \\
& $\mathbf{1 1 : 0 0}$ & $3.16 \pm 0.11$ & $1.85 \pm 0.12$ & $0.02 \pm 0.01$ & $0.09 \pm 0.02$ \\
& Mean & $\mathbf{3 . 0 7} \pm \mathbf{0 . 1 1}$ & $\mathbf{1 . 7 0} \pm \mathbf{0 . 1 6}$ & $\mathbf{0 . 0 2} \pm \mathbf{0 . 0 1}$ & $\mathbf{0 . 0 5} \pm \mathbf{0 . 0 1}$ \\
CD for Varieties $(\boldsymbol{P} \leqq \mathbf{0 . 0 5})$ & $\mathbf{0 . 0 7 2}$ & $\mathbf{0 . 0 4 1}$ & $\mathbf{0 . 0 0 1}$ & $\mathbf{0 . 0 0 7}$ \\
CD for Time $(\boldsymbol{P} \leqq \mathbf{0 . 0 5})$ & $\mathbf{0 . 0 8 8}$ & $\mathbf{0 . 0 5 1}$ & $\mathbf{0 . 0 0 1}$ & $\mathbf{0 . 0 0 8}$ \\
CD for V $\mathbf{X} \mathbf{T}(\boldsymbol{P} \leqq \mathbf{0 . 0 5})$ & $\mathbf{0 . 1 2 5}$ & $\mathbf{0 . 0 7 2}$ & $\mathbf{0 . 0 0 2}$ & $\mathbf{0 . 0 1 2}$ \\
\hline
\end{tabular}


observed that most of the metabolites increased at $2 \mathrm{hrs}$ after anthesis in cv. Amrapali compared to Alphonso where the metabolites decreased after anthesis. The study suggests that the above metabolites especially hormones along with maintenance of metabolites after anther dehiscence plays an important role in higher viability and fruit set in mango crop. This is one of the first studies on mango pollen metabolites.

\section{ACKNOWLEDGEMENT}

The current study was supported by ICAR project "National Innovations on Climate Resilient Agriculture (NICRA)" New Delhi. All the authors are thankful to the Director, ICAR-IIHR, Bengaluru for providing the necessary facilities to carry out the work.

\section{REFERENCES}

Abourayya, M.S., Kassim, N.E., El-Sheikh, M.H. and Rakha, A.M. 2011. Comparative study between inflorescence characteristics, pollen viability, germination and dimensions of Tommy Atkins, Kent and Keitt mango cultivars. Life Sci. J. 8 (1):100-105.

Abd El-Hadi, S.M.K. 2006. Evaluation studies on some mango varieties. Fac. Agric., Al-Azhar Univ., Egypt, pp. 166 (M.Sc. Thesis).

Aloni, B., Peet, M.M., Pharr, M. and Karni, L. 2001. The effect of high temperature and high atmospheric $\mathrm{CO}_{2}$ on carbohydrate changes in bell pepper (Capsicum annuum) pollen in relation to its germination. Physiol. Plant. 112:505-512.

Aloni, R., Aloni, E., Langhans, M. and Ullrich, C.I. 2006. Role of auxin in regulating Arabidopsis flower development. Planta 223:315-328.

Basuny, A.M., Arafat, S.M. and Soliman, H.M. 2013. Chemical analysis of olive and palm pollen: antioxidant and antimicrobial activation properties. Wudpecker J. Food Tech. 1:1421.

Cecchetti, V., Altamura, M.M., Brunetti, P., Petrocelli, V., Falasca, G., Ljung, K., Costantino, P. and Cardarelli, M. 2013. Auxin controls Arabidopsis anther dehiscence by regulating endothecium lignification and jasmonic acid biosynthesis. Plant J. 74:411422.

Cheng, Y., Dai, X. and Zhao, Y. 2006. Auxin biosynthesis by the yucca flavin monooxygenases controls the formation of floral organs and vascular tissues in Arabidopsis. Genes Dev. 20:1790-1799.
Chhun, T., Aya, K., Asano, K., Yamamoto, E., Morinaka, Y., Watanabe, M., Kitano, H., Ashikari, M., Matsuoka, M. and UeguchiTanaka, M. 2007. Gibberellin regulates pollen viability and pollen tube growth in rice. Plant Cell 19:3876-3888.

Dahshan, D.I.M. 1971. Studies concerning growth and fruiting in some mango varieties. Fac. Agric. Ain Shams Univ., Egypt, pp.171 (M.Sc. Thesis).

Desai, A.G., Limaye, V.P. and Gunjate, R.T. 1985. Floral biology of Alphonso, Goamankur and Kesar varieties of mango. J Maharashtra Agric. Univ, 10(2):193-195.

da Silva, G.R., da Natividade, T.B., Camara, C.A., da Silva, E.M.S., de Assis Ribeiro dos Santos, F. and Silva, T.M.S. 2014. Identification of sugar, amino acids and minerals from the pollen of Jandaíra stingless bees (Melipona subnitida). Food Nutri. Sci. 5(11):1015-1021.

Davenport, T.L. 2009. Reproductive physiology. In: Litz, R.E. (Ed.), The Mango: Botany Production and Uses, $2^{\text {nd }}$ edition. CAB International, Wallingford, UK, pp. 97-169.

El-Kady, M.I.E. 1973. Physiological studies on flowering and fruit set in some mango varieties especially in Taimour. Fac. Agric., Cairo Univ., Egypt, pp. 195 (M.Sc.Thesis).

El-Masry, S.M. 2001. Selection of some mango seedlings grown in Assiut. Fac. Agric., Assiut Univ., Egypt, pp. 195 (Ph.D. Thesis).

Geetha, G.A., Shivashankara, K.S. and Roy, T.K. 2016. Floral biology and stigma biochemistry of mango cultivars with contrasting fruit set. Indian J. Plant Physiol. 21(4):537-544. 
Gillaspy, G., Ben-David, H. and Gruissem, W. 1993. Fruits: a developmental perspective. The Plant Cell 5:1439-1451. Missing in text?

Goto, N. and Pharis, R.P. 1999. Role of gibberellins in the development of floral organs of the gibberellin-deficient mutant, ga1-1, of Arabidopsis thaliana. Can. J. Bot. 77:944-954.

Hassan, M.M. 2011. Chemical Composition and Nutritional Value of Palm Pollen Grains. Global J. Biotechnol. Biochem. 6(1):1-7.

Herrero, M. 2003. Male and female synchrony and the regulation of mating in flowering plants. Philosop. Trans. Royal Soc. London Ser. B Bio. Sci. 358:1019-1024.

Issarakraisila, M. and Considine, J.A. 1994. Effect of temperature on pollen viability in Mango cv. Kensington. Ann. Bot. 73(3):231-240.

Issarakraisila, M., Considine, J.A. and Turner, D.W. 1992. Seasonal effects on floral biology and fruit set of mangoes in a warm temperature region of Western Australia. Acta Horti. 321:626-635.

Kedzia, B. and Holderna-Kedzia, E. 2012. New studies on biological properties of pollen. PostepyFitoterapii, 1:48-54.

Koul, A.K. and Paliwal, R.L. 1961. Inorganic acid test for pollen viability. Agra univer. J. Res. Sci. 10:85-90.

Kovaleva, L. and Zakharova, E. 2003. Hormonal status of the pollen-pistil system at the progamic phase of fertilization after compatible and incompatible pollination in petunia hybrida L. Sex Plant Reprod. 16:191-196.

Kovaleva, L.V. and Zakharova, E.V. 2004. Gametophyte- sporophyte interactions in the pollen-pistil system: 4 . The hormonal status and the mechanism of self-incompatibility. Russ. $J$. Plant Physiol., Engl. Transl. pp.402-406.

Leah Karni and Beny Aloni. 2002. Fructokinase and hexokinase from pollen grains of bell pepper (Capsicum annuum L.): possible role in pollen germination under conditions of high temperature and $\mathrm{CO}_{2}$ enrichment. Ann Bot. 90(5):607-612.
Mallik, P.C. 1957. Morphology and biology of the mango flower. Indian J. Hort. 4:1-23.

Mattioli, R., Biancucci, M., Lonoce, C., Costantino, P. and Trovato, M. 2012. Proline is required for male gametophyte development in Arabidopsis. BMC Plant Biol.12(1):236.

Mol, R., Filek, M., Machackova, I. and MatthysRochon, E. 2004. Ethylene synthesis and auxin augmentation in pistil tissues are important for egg cell differentiation after pollination in maize. Plant Cell Physiol. 45:1396-1405.

Mukherjee, S.K. 1949. The mango and its relatives. Sci. cult. 15:5-9.

Mutters, R.G., Ferreira, L.G.R. and Hall, A.E. 1989. Proline content of the anthers and pollen of heat tolerant and heat-sensitive cowpea subjected to different temperatures. Crop Sci. 29:14971500 .

Nishiyama, I. 1984. Climatic influence on pollen formation and fertilisation. In: Tsunoda, S., Takahashi, N., eds. Biology of rie. Tokyo; Japan scientific societies press, 153-171.

Owens, J.N., Simpson, S.J. and Molder, M. 1980. The pollination mechanism in yellow cypress (Chamaecyparis nootkatensis). Can. J. Forest Res. 10:564-572.

Parish, R.W., Phan, H.A., Iacuone, S. and Li, S.F. 2013. Tapetal development and abiotic stress: A centre of vulnerability. Funct. Plant Biol. 39:553-559.

Pimentel, R.B., Coronel, R.E. and Espino, R.F.C. 1984. Floral biology and fruit set in mango (Mangifera indica L.) cultivars: 'Carabao', 'Pico' and 'KanchaMitha'. Philippine J. Crop Sci. 9:47-51.

Randhawa, G.S. and Damodaran, V.K. 1961. Studies on floral biology and sex ratio in mango (Mangifera indica L.) I. A review. Indian J. Horti. 18:9-35.

Roulston, T.H. and Cane, J.H. 2000. Pollen nutritional content and digestibility for animals. Plant Sys. Evol. 222(1-4):187-209.

Sen, P.K., Mallik, P.C. and Ganguly, B.D. 1946. Hybridization of the mango. Indian J. Hort, 4(4). 
Singh, R.N. 1954. Studies in floral biology and subsequent development of fruits in the Mango (Mangifera indica L.) dasheri and langra. Indian J. Horti. 11(3):69-88.

Singh, S.N. 1963. Studies on the morphology, viability and preservation of pollen grains of mango (Mangifera indica L.), litchi (Litchi chinensis Sonn.) and loquat (Eriobothrya japonica Lind!). Agra Univer. J. Res. Sci. 12:317-322.

Singh, S.N. and Singh, A.P. 1961. Studies on the morphology and viability of the pollen grains of mango. Hort. Adv. 5:121-144.

Spencer, J.L. and Kennard, W.C. 1955. Studies on Mango (Mangifera indica L.) fruit set in Puerto Rico. Tropical Agri.Trin. 32:323-330.

Stanley, R.G. and Linskens, H.F. 1974. Pollen: biology, biochemistry, management. $1^{\text {st }}$ edn. Springer, Heidelberg, Germany.
Stosser, R., Hartman, W. and Anvari, S.F. 1996. General aspects of pollination and fertilization of pome and stone fruits. Acta Horti. 423:15-21.

Szczesna, T. 2006. Long chain fatty acids composition of honeybee collected pollen. J. Apicult. Sci. 50:65-79.

Tsang, M.J. and Chang, W.N. 1983. Effects of temperature and growth regulators on flowering and fruit set of mango. J. Chin. Soc. Horti. Sci. 29:87-95.

Wu, J., Qin, Y. and Zhao, J. 2008. Pollen tube growth is affected by exogenous hormones and correlated with hormone changes in styles in Torenia fournieri L. Plant growth regul. 55(2):137-148.

Young, T.W. 1955. Influence of temperature on growth of mango pollen. Pro. Florida State Horti. Soc. 68:308-313.

(MS Received 17 December 2018, Revised 04 May 2019, Accepted 10 June 2019) 